\title{
EKSISTENSI DIRI TIGA PEREMPUAN \\ DALAM TROIS FEMMES PUISSANTES KARYA MARIE NDIAYE
}

\author{
Yeni Artanti, Diajeng Sofyanti, Muhammad Deni Reza P., \& Wiwin Hartanti \\ Universitas Negeri Yogyakarta \\ email: yenarta@uny.ac.id
}

\begin{abstract}
Abstrak
Manusia sepanjang hidupnya secara terus-menerus melakukan tindakantindakan untuk menunjukkan keberadaan dirinya. Tujuan penelitian ini adalah untuk mendeskripsikan eksistensi diri ketiga perempuan yang terepresentasi dalam Trois Femmes Puissantes karya Marie Ndiaye. Penelitian ini adalah penelitian deskriptif kualitatif dengan teknik analisis interpretatif dengan menggunakan pendekatan eksistensialisme sebagai acuan analisis. Data-data berupa kata, frasa, kalimat atau paragraf terkait eksistensi ketiga tokoh perempuan, yaitu Norah, Fanta, dan Khady Demba yang terkumpul melalui pembacaan secara berulang, pencatatan, pengelompokan atau pengklasifikasian kemudian dianalisis dan diinterpretasikan untuk disajikan. Hasil penelitian menunjukkan bahwa ketiga perempuan yaitu Norah, Fanta, dan Khady Demba merepresentasikan tokoh-tokoh yang mencoba melakukan perlawanan terhadap dominasi kulit putih, dunia patriarki, dan kapital dengan mencoba menjadikan diri mereka 'ada.' Ketiganya meng'ada' dengan menjadi pribadi yang bertindak terhadap hidup mereka. Kecemasan, ketakutan, kepedihan, penderitaan, pengalaman traumatis, emosi dan juga keputusasaan yang seringkali mengungkung perempuan, dijadikan sebagai pengalaman eksistensi untuk meng'ada' sebagai perempuan dan pribadi. Kegetiran hidup Norah karena trauma kehilangan sosok ayah, ikatan cinta suami Fanta yang memenjarakan, dan jeratan kebutuhan ekonomi yang melilit Khady Demba tidak membuat tiga perempuan ini putus asa, tetapi justru menjadikan mereka sebagai individu yang konkret dan unik dalam memilih eksistensi mereka sendiri, yaitu sebagai pengacara, ibu rumah tangga, atau pekerja seks, setidaknya mereka memilih untuk bertindak dengan sadar. Ketiganya menyadari keberadaannya sebagai manusia.
\end{abstract}

Kata Kunci: eksistensi, perempuan, Ndiaye, kedirian, pergumulan batin

\section{THE SELF-EXISTENCE OF THREE WOMEN IN MARIE NDIAYE'S TROIS FEMME PUISSANTES}

\begin{abstract}
Humans throughout their life continuously take actions to show their existence. The purpose of this research is to describe the existence of the three women represented in Marie Ndiaye's "Trois Femmes Puissantes." This research is a qualitative descriptive study by using interpretive analysis techniques and an existentialism approach as a reference for analysis. Data in the form of words, phrases, sentences or paragraphs related to the existence of the three female characters, namely Norah, Fanta, and
\end{abstract}


Khady Demba which were collected through repeated reading, note taking, grouping or classifying, and analysing or interpreting. The results showed that the three women stated represented figures who tried to fight against white domination, patriarchy and capital domination. The three of them are becoming individuals who act and own their life to show their existence. Anxiety, fear, pain, suffering, traumatic experiences, emotions, and despair that often confine women, are interpreted as their experiences as a woman and as a person. Norah's life bitterness due to the traumatic feeling of losing a father's figure, the love bond of Fanta's imprisoned husband, and the bondage of economic necessity that surrounds Khady Demba did not make these three women despair, but instead made them concrete and unique individuals in choosing their own existence, explicitly as lawyer, housewife, or sex worker. They choose to act and show their existence consciously.

Keywords: existence, women, Ndiaye, self, inner struggle

\section{PENDAHULUAN}

Secara etimologis, kata 'perempuan' berasal dari kata empu yang berarti tuan, orang yang mahir/berkuasa, atau kepala, hulu, dan yang paling besar (Yuliawati, 2018: 54). Dengan kata lain, perempuan dapat dimaknai sebagai seorang yang berkuasa dan memiliki peran penting dalam kehidupan masyarakat. Namun, sering kali hal tersebut tidak berlaku dalam budaya patriaki. Stigma-stigma tertentu sering kali diberikan kepada perempuan yang justru memperlemah kedudukan mereka secara sosial, ekonomi maupun politik (Syafe'i, 2015:147), misalnya perempuan dianggap sebagai sosok yang lemah, mudah terbawa perasaan dan tidak rasional (Harjito, 2014: 316). Anggapan umum yang berlaku (baik secara sadar maupun tak sadar) pada masyarakat yang dilekatkan pada peran perempuan sering kali masih seputar urusan dapur, sumur, dan kasur. Hal tersebut menimbulkan keprihatinan tersendiri, karena seharusnya perempuan mempunyai hak yang sama dalam menentukan perannya dalam berbagai aspek kehidupan.
Karya sastra merupakan kristalisasi nilai-nilai budaya yang ada dalam masyarakat. Pengarang sebagai anggota suatu masyarakat mengekspresikan nilai-nilai tertentu melalui karyanya dengan media bahasa. Pengarang tidaklah menciptakan karyanya dengan pikiran yang 'hampa' tanpa ada 'sesuatu' referensi terhadap apa yang ingin disampaikannya. Beberapa penelitian sastra tentang perempuan membuktikan bahwa perempuan masih mengalami tekanan-tekanan terhadap pandangan masyarakat. Itu sebabnya, karya sastra selalu dikatakan tidak dapat kebal terhadap nilai-nilai kemanusiaan yang ada di dunia luar karya sastra (Artanti, 2020) termasuk menyangkut permasalahan-permasalahan yang terjadi pada masyarakat misalnya terkait ketimpangan gender, rasialisme, sentimen agama atau konflik-konflik sosial lainnya. Kajian Ari Nurhayati (2019)membuktikan bahwa masyarakat Afrika-Amerika yang terepresentasi melalui novel The Bluest Eye dan God Help the Child karya Toni Morrison menunjukkan bahwa perempuan 
masih mengalami opresi sebagai akibat dari hegemoni kecantikan kulit putih sehingga membuat perempuan Afrika-Amerika menjadi inferior dan membenci diri mereka sendiri karena secara fisik berada di bawah standard kecantikan ideal.

Salah satu karya sastra Prancis yang merepresentasikan nilai-nilai tentang perempuan yaitu Trois Femmes Puissantes karya Marie Ndiaye. Roman ini diterbitkan pertama kali oleh Penerbit Gallimard pada tahun 2009 dan telah diterjemahkan ke dalam berbagai bahasa, namun hingga saat ini belum ada terjemahan dalam bahasa Indonesia. Melalui roman Trois Femmes Puissantes untuk pertama kalinya Marie Ndiaye, secara eksplisit mengukuhkan karya sastra berbahasa Prancis tentang Afrika, tempat tinggal ayahnya. Orang bisa berhipotesis bahwa hubungan novelis dengan benua Afrika yang penuh teka-teki menjadi salah satu dari banyak faktor yang membuat Juri Prix Goncourt terpesona, hingga memilih Trois Femmes Puissantes sebagai penerima penghargaan di tahun 2009. Dengan karya ini, Marie NDiaye menulis tentang tentang gangguan identitasnya, biasa disebut persilangannya yang terpotong. Sebagaimana Marie NDiaye mendefinisikannya ke-Afrikaannya. Dengan cara yang sangat berbeda dalam setiap kisah yang terdapat dalam roman ini (Nina: 2013).

Beberapa kajian telah dilakukan terhadap roman Trois Femme Puissantes, yang untuk untuk selanjutnya dalam penelitian ini disingkat TFP, antara lain dilakukan oleh Abdoulaye Imorou yang mencoba untuk mendeskripsikan ketiga perempuan yang kuat dalam roman. Melalui artikelnya yang berjudul "Humaines et épanouies. TFP et Les Figures littéraires des Africaines" yang diterbitkan oleh Association for French Studies in Southern Africa (AFSSA) pada tahun 2013 terungkap bahwa ketiga tokoh perempuan merupakan tokoh yang kuat karena mampu melawan proses dehumanisasi lingkungan selagi mengklaim tentang hak yang dimiliki setiap manusia yaitu hidup bahagia. Selain itu, melalui karya ini, Marie NDiaye tampaknya mengikuti gambaran umum orang Afrika yang muncul dalam sastra, yaitu memposisikan perempuan sebagai korban, objek dan sekaligus melakukan perlawanan.

Kajianlain dilakukanolehMalyoune Benoit dalam artikelnya berjudul Dire la migration, "Khady Demba» dans TFP de Marie Ndiaye yang diterbitkan pada Jurnal The African Literature Association (2019). Penelitian ini mendeskripsikan kategori-kategori adanya motivasi-motivasi sosial, ekonomi, dan politik ketiga tokoh perempuan kuat yang ada di dalam bahwa teks roman TFP.

Dalam penelitian lain yang berjudul À leur corps défendant : défaillances et excrétions dans TFP de Marie NDiaye yang dikaji oleh Anne Martine Parent pada tahun 2013, menjelaskan bahwa keberadaan tubuh dan ekspresiekspresi tubuh tokoh-tokoh perempuan ini memainkan peran penting dalam narasi. Tokoh-tokoh perempuan dalam roman TFP (2009) digambarkan sebagai perempuan yang terpinggirkan, distigmatisasi, dikucilkan, terjebak pada rasa bersalah dan / atau malu, tidak bisa lepas dari dirinya sendiri dan ketidakmampuan untuk memisahkan diri dari diri sendiri ini ditandai dalam 
tubuh yang menjadi tempat demonstrasi dan semua jenis ekskresi: kemerahan, tremor, pusing, mual, berkeringat, air mata, dorongan tak tertahankan untuk buang air kecil. Tubuh dalam roman TFP (2009) alih-alih menandakan integritas dan identitas subjek, menjadi tanda kerentanan, kegagalan fisik yang mengungkap gangguan identitas terhadap subjektifitas dan tidak mempunyai solusi untuk keberhasilan diri.

Deborah B. Gaensbauer mengungkapkan tentang masalah migrasi melalui artikelnya Migration and Metamorphosis in Marie Ndiaye's "Trois Femme Puissantes" (2014), menunjukkan bahwa roman ini menggambarkan perpindahan dan juga peralihan beberapa sudut pandang (Bakhtin menyebutnya sebagai polifonik), semifantastik dari perpindahan satu identitas tokoh ke identitas tokoh lain dengan latar belakang sosio-geografis yang berbeda. Dalam bagian Counterpoint di bagian akhir tiap cerita, yang biasanya digunakan dalam musik, merupakan suatu hal yang baru karena memberikan fokus baru dan kejadian tak terduga yang memperumit interpretasi perilaku karakter dalam roman. Masingmasing tokoh perempuan digambarkan bermetamorfosis menjadi burung atau persona mirip burung. Artikel ini juga mengkaji inovasi perubahan bentuk realitas sosial-politik yang mengerikan dan penuh ambiguitas melalui fantasi dan takhayul untuk menyampaikan hubungan kekuasaan yang tidak manusiawi dan tidak setara tentang proses perjuangan migrasi perempuan kontemporer Afrika terhadap Eropa.

Di antara penelitian-penelitian yang telah dilakukan oleh para peneliti terdahulu seperti tersebut di atas, fokus pada penelitian ini adalah tentang eksistensi diri atau ke'dirian' ketiga perempuan dalam TFP (2009) karya Marie Ndiaye. Pengkajian terhadap TFP (2009) akan difokuskan dengan menggunakan pendekatan eksistensi berdasarkan teori Søren Kiekegaard dengan beberapa alasan, yaitu (1) trauma-trauma ketiga perempuan dalam roman merupakan pengalaman eksistensial menjadi manusia, (2) untuk bereksistensi ketiga perempuan, seperti juga manusia pada umumnya bergerak meninggalkan zona nyaman dan perjuang untuk menjadi manusia yang lebih baik, (3) ketiga perempuan ini mendidik dirinya sendiri untuk bebas dalam melihat dirinya sendiri atau mendefinisikan dirinya sendiri.

Eksistensialisme adalah cara manusia berada di dunia. Istilah eksistensi berasal dari kata 'eks' atau keluardan 'sistensi' yangditurunkandari kata kerja 'sisto' yang berarti 'berdiri' atau 'menempatkan.' Jadi eksistensi dapat diartikan sebagai manusia berdiri sebagai diri sendiri dengan keluar dari dirinya, manusia menjadi sadar bahwa dirinya ada (Hadiwijono, 2016: 148). Meskipun istilah «eksistensialisme» secara tradisional terkenal sulit untuk didefinisikan karena fakta bahwa kata tersebut telah melekat pada begitu banyak karya para pemikir dan penulis dengantema-temayangberagam, namun secara implisit ataupun eksplitsit kaum eksistensialis sebenarnya terpengaruh oleh pandangan Kierkegaard. Dalam pandangan eksistensialis, Kiekegaard meletakkan dasar pemikiran terhadap keberadaan manusia sebagai individu yang terus-menerus melawan ketidakautentikan diri, yang dihadapkan pada 
publik sebagai kesatuan yang abstrak yang merupakan kumpulan orangorang yang bersembunyi dari rasa takut dalam menggapai eksistenisinya sendiri (Garot, 2017). Menurut Gregor Malantschuk, salah seorang peneliti karya-karya Kierkegaard, Kierkegaard sejak awal menyadari bahwa eksistensi manusia terdiri dari tiga elemen, yaitu subjek (diri), kebebasan, dan etika yang ketiganya saling berkaitan. Subjek adalah pelaku yang dalamkebebasannya selalu mengambil keputusan-keputusan terkait dengan kebebasannya, yang dalam mencapai kebebasannya selalu terkait dengan moralitas tindakan (etika). (Garot, 2017:38).

Dalam kesusastraan Prancis, romanroman bertema perempuan imigran cukup jarang digali. TFP (2009), karya Marie Ndiaye memberikan wawasan baru tentang tiga perempuan dengan latar ruang dan tokoh imigran Afrika, khususnya Senegal (Benoit, 2019: 218). Roman ini terdiri dari tiga cerita berbeda tentang tiga perempuan imigran. Sebagai seorang imigran yang sekaligus penulis perempuan, Marie NDiaye sering menghadirkan tokohtokoh perempuan, dengan berbagai kepribadian, yang sebagian besar dicitrakan sebagai imigran berasal dari Afrika melalui karya-karyanya. Salah satu roman karyanya adalah berjudul Trois Femmes Puissantes yang diterbitkan oleh penerbit Gallimard pada tahun 2009 dan memenangkan Le Prix Goncourt pada tahun yang sama. Roman ini menceritakan tiga kisah dengan tiga tokoh yang berbeda yaitu, Norah, Fanta dan Khady Demba. Meskipun disajikan dalam cerita yang berbeda dan terpisah, ketiga tokoh tersebut disatukan oleh "kekuatan" dari pribadi masing-masing. Ketiga tokoh perempuan dalam roman ini menarik untuk dikaji karena masing-masing memiliki permasalahan yang kompleks untuk diselesaikan dengan cara yang unik dan menunjukkan ke'dirian' para tokohnya.

\section{METODE}

Penelitian ini adalah penelitian deskrtiptif kualitatif. Sumber data utama adalah ketiga cerita (Cerita I, II, III) roman Trois Femmes Puissantes karya Marie NDiaye yang diterbitkan oleh Penerbit Gallimard pada tahun 2009. Data penelitian ini berupa kata, frasa, kalimat, atau paragraf yang menunjukkan eksistensi diri ketiga perempuan dalam roman, yaitu Norah, Fanta, dan Khady Demba. Metode pengumpulan data yang digunakan dalam penelitian ini dilakukan dengan cara membaca, mengidentifikasi, mencatat, membuat tabel, dan pengkategorian data.

Adapun langkah-langkah yang dilakukan dalam pengumpulan data meliputi (1) membaca dengan cermat dan berulang-ulang keseluruhan cerita bagian pertama sampai ketiga roman Trois Femmes Puissantes; (2) mengidentifikasi bagian-bagian tertentu yang ada pada cerita yang mengandung data yang diperlukan sesuai dengan permasalahan dalam penelitian; (3) mencatat hasil identifikasi data yang berupa kutipan-kutipan baik berupa kata, frasa, kalimat, dan paragraf; (4) pengkategorian pada setiap data yang telah terkumpul, (5) menganalisis atau menginterpretasi data untuk disajikan. Instrumen penelitian dalam pengumpulan data berupa tabel data yang digunakan 
peneliti untuk mengklasifikasikan data-data ke dalam unit-unit untuk dianalisis dan diinterpretasikan guna menjawab pertanyaanpertanyaan dalam penelitian untuk kemudian dideskripsikan dan ditarik kesimpulannya.

\section{HASIL DAN PEMBAHASAN Hasil}

Manusia terlahir ke dunia untuk menjalani kehidupannya masingmasing. Peristiwa-peristiwa praktis sehari-hari justru menjadikan manusia menjadi bermakna, menjadi manusia yang konkrit. Dirangkum melalui Hadiwijono (2016:124), persoalanpersoalan hidup oleh Kiekergaard disebut sebagai 'persoalan eksistensial,' yang setiap orang dihadapkan pada persoalannya sendiri-sendiri setiap harinya, khusus untuknya sendiri yang tidak mungkin dijawab atau diselesaikan secara bersama-sama.

Eksistensi manusia merupakan suatu tindakan atau perbuatan bebas untuk memilih yang harus dilakukan oleh tiap-tiap orang bagi dirinya sendiri. Kiekergaard menegaskan bahwa subjektifitas merupakan kebenaran pertama dan menjadi dasar eksistensi pribadi yang menjadi tugas bagi setiap manusia, "... becoming subjective is the task proposed to every humin being." (Hassan, 2014: 155). Kesadaran terhadap 'Aku' merupakan asal usul pengetahuan manusia. Konsep 'Aku' adalah konsep subjektivitas yang identik dengan kedalaman, keterlibatan, keberadaan dan eksistensi. Selanjutnya, istilah 'Aku' hanya mungkin oleh karena tubuh. Manusia dengan segala pengamanannya, hadir melalui tubuhnya. (Riyanto, 2018: 189\&227).
Melalui roman TFP (2009), ke-'Aku-an atau pengalaman subjektifitas ketiga tokoh disajikan pada Tabel 1.

\section{Pembahasan}

Pengalaman-pengalaman subjektif seseorang menentukan keberadaanya. Manusia memiliki kebebasan untuk memilih cara hidupnya sendiri. Manusia memiliki kebebasan untuk memilih cara hidupnya sendiri dengan begitu manusia menjadi bertanggung jawab terhadap eksistensinya. Pandangan-pandangan hidup seseorang akan tercermin melalui tindakan-tindakannya seharihari. Subjektifitas yang menjadi tugas setiap manusia, eksistensi bagi manusia merupakan tugas yang harus dijalani setiap manusia dengan penuh makna, dihayati sebagai sesuatu yang etis dan religius (Hassan, 2014 : 156). Bagi Kierkegaard, wilayaheksistensimanusia atau tahap-tahap jalan hidup manusia terdiri dari tiga hal yang penting, yaitu tahap estetis, etis, dan religius (Garot, 2017 :42-50 ; Hadiwijono, 2016:124-125). Roman TFP (2009), merepresentasikan ketiga perempuan, yaitu Norah, Fanta, dan Khady Demba. Ketiganya meng'ada' dengan menjadi pribadi yang bertindak terhadap hidup mereka. Kecemasan, ketakutan, kepedihan, penderitaan, pengalaman traumatis, emosi dan juga keputusasaan yang seringkali mengungkung dijadikan sebagai pengalaman eksistensi untuk menjadikan diri mereka 'ada' sebagai perempuan dan pribadi.

Melalui roman TFP (2009), ketiga tokoh perempuan yaitu Norah, Fanta dan Khady Demba digambarkan sebagai tokoh yang secara fisik digambarkan sebagai perempuan yang bergumul sebagai individu tentang ke- 


\section{Tabel 1. Pengalaman Subjektifitas Tiga Tokoh Perempuan dalam TFP (2009)}

\begin{tabular}{|c|c|c|}
\hline No & Tokoh & Pengalaman Subjektif \\
\hline 1. & Norah & $\begin{array}{l}\text { - Trauma ditinggal ayahnya kembali ke Afrika ketika berusia } 8 \text { tahun. } \\
\text { - Hidup bersama saudara perempuan dan Ibunya di Paris. } \\
\text { - Hidup miskin di Paris, untuk menghidupi kedua anaknya, ibunya bekerja sebagai pekerja } \\
\text { - Beks. } \\
\text { - Merjuang melupakan kepedihan karena merasa tidak diinginkan. } \\
\text { - Menikah untuk kedua kali dengan Jakob Ganzer. } \\
\text { - Memiliki anak bernama Lucie dan anak tiri dari Jakob bernama Greeta. } \\
\text { - Mencoba berdamai dengan keadaaan dan memaafkan Ayahnya dan bersedia } \\
\text { membantunya untuk membela adik laki-lakinya yang dipenjara atas tuduhan } \\
\text { pembunuhan. } \\
\text { - Pribadi pemaaf dan tumbuh, usianya } 38^{\text {th }} \text {. }\end{array}$ \\
\hline 2. & Fanta & $\begin{array}{l}\text { - Memutuskan untuk meninggalkan pekerjaannya sebagai guru sastra di sekolah Mermoz, } \\
\text { - Kenegal. } \\
\text { Keputusan untuk mengikuti suaminya, Rudy Descas ke Prancis. Rudy adalah mantan guru } \\
\text { - Kehidupan miskin dan tidak sesuai harapan di Prancis. } \\
\text { - Kepribadian suaminya yang ternyata emosional dan kasar serta tidak stabil emosi dan } \\
\text { tindakannya yang disebabkan oleh trauma masa kecilnya tentang pembunuhan yang } \\
\text { dilakukan ayahnya terhadap rekan kerjanya yang membuatnya dipenjara hingga bunuh } \\
\text { diri. Kebencian Rudy terhadap ayahnya. } \\
\text { - Kekecewaan terhadap keadaan di Prancis bersama suaminya, Rudy Descas yang ternyata } \\
\text { terlalu terikat dengan keluarga besarnya, terutama Ibunya yang membenci Fanta. } \\
\text { - Menjadi pribadi yang pendiam dan menyedihkan menyadari terhadap penolakan } \\
\text { lingkungan dan keluarga suaminya. } \\
\text { - Konsentrasi pada membesarkan dan mengurus anaknya, Djibril. } \\
\text { - Tidak berdaya terhadap cinta Rudy yang dingin, mengecewakan, menyiksa, dan tidak } \\
\text { membahagiakan. } \\
\text { - Kesadaran Rudy bahwa yang menyebabkan kematian Ayahnya di penjara adalah senjata } \\
\text { yang diberikan oleh Ibunya. } \\
\text { - Kesadaran Rudy tentang Ibunya yang ternyata memiliki kepribadian yang mengerikan. } \\
\text { - Dalam diam, percaya terhadap ketetapan Tuhan akan hidup dan nasibnya. }\end{array}$ \\
\hline 3. & $\begin{array}{l}\text { Khady } \\
\text { Demba }\end{array}$ & $\begin{array}{l}\text { - Memiliki trauma ditinggal kedua orang tuanya dan diasuh oleh neneknya. } \\
\text { - Menikah dengan laki-laki yang mencintainya meskipun miskin. } \\
\text { - Pernikahan yang tidak berlangsung lama karena suaminya meninggal. } \\
\text { - Selama menikah tinggal di rumah keluarga suaminya yang sempit dan memprihatinkan. } \\
\text { - Menjadi janda di usia muda tanpa memiliki anak dari suaminya, kecewa terhadap } \\
\text { - Bekerja sebagai pembantu di rumah ayah Norah. } \\
\text { - Tinggal bersama keluarga besar suaminya yang miskin dan tidak menyukainya, } \\
\text { mengalami penolakan. } \\
\text { - Diusir oleh mantan Ibu Mertuanya untuk pergi ke Prancis mencari pekerjaan, } \\
\text { - Berbekal tulisan nama Fanta, sepupu jauh suaminya, dan alamatnya, Khady Demba } \\
\text { mengikuti perintah mertuanya menuju Prancis. } \\
\text { - Lompat dari perahu yang akan membawanya menuju Prancis, membuat kakinya terluka } \\
\text { dan terdampar di pantai. } \\
\text { - Dibantu oleh Lamine, anak remaja yang juga mengalami trauma masa lalu. } \\
\text { - Memakan ekonomi menjadikannya sebagai pekerja seks. } \\
\text { Paspor, berganti nama dan menyogok. } \\
\text { - Penghianatan dan perampokan yang dilakukan Lamine, anak remaja yang } \\
\text { membantunya, menjadikan Khady Demba kembali hidup sebatang kara, kesepian dan } \\
\text { menderita. }\end{array}$ \\
\hline
\end{tabular}


diri-an mereka sebagai perempuan yang secara fisik berbeda dengan yang lain, yang unik dan memiliki ciri-ciri berkulit hitam. Ciri-ciri fisik atau tubuh selalu dikaitkan dengan ras dan etnik tertentu. Terdapat efek-efek psikologis yang ditimbulkan dari pembedaan manusia berdasarkan rasisme yang pemunculkan kolonialisme (Ritzer \& Stepnisky, 2019: 586-587), yaitu munculnya dikotomi tuan - budak, dehumanisasi yang berlangsung sebagai objektifikasi tubuh manusia, merepresentasikan struktur keseluruhan kekuasaan dan rasisme kolonial.

Hubungan dikotomis tuan - budak menjadi benang merah yang mengikat cerita yang satu dengan cerita yang lainnya. Khady Demba, perempuan tokoh utama dalam cerita ketiga, merupakan perempuan muda yang bekerja sebagai pembantu / pengasuh anak di rumah Ayah Norah di Dakkar, Senegal. Kehadiran Khady Demba pada cerita pertama, hanya muncul sekilas dalam pertemuannya dengan Norah di rumah Ayahnya."Khady Demba, la tranquille fierté de sa voix ferme, de son regard direct étonna Norah, l'apaisa, chasse un peu l'irritation de son coeur, la fatigue inquiete et le ressentiment." «Khady Demba, suaranya tegas, tenang, penuh kebanggaan, (dia menjawab Norah) dengan tatapan langsung yang membuat Norah takjub, sedikit tenang, menghapus rasa benci, lelah, dan tidak nyaman yang bergejolak (sejak kedatangannya kembali ke rumah Ayahnya di Dakkar).» (TFP, 2009:23-24). Demikian juga keterkaitan perempuan kedua dan ketiga, Fanta dan Khady Demba. Fanta merupakan sepupu jauh dari mendiang suami Khady Demba yang meskipun tidak sempat bertemu, berbekal alamat Fanta di Prancislah, Khady Demba menguji nasibnya menjadi imigran gelap dan bekerja sebagai pekerja seks.

\section{Pengalaman Subjektif dan Eksistensi Norah}

Norah dalam cerita pertama merupakan perempuan berayah Senegal tetapi memiliki Ibu seorang Prancis yang tinggal bersama Ibunya dalam kondisi miskin dan harus menghidupi diri sendiri dan kedua anaknya (Norah dan saudara perempuan) semenjak ayahnya kembali ke Senegal dengan membawa serta saudara laki-laki Norah. Hidup dengan pengalaman traumatis (tidak diinginkan dan ditinggalkan ayah) sejak kecil hingga menjadi dewasa dan mencapai pendidikan atas usahanya sendiri sebagai pengacara di Prancis, Norah diminta kembali ke Senegal untuk membantu ayahnya yang telah bangkrut dan adiknya yang masuk penjara atas tuduhan pembunuhan. Trauma pribadi ditinggal seorang ayah dan konflik-konflik batin yang terjadi di dalam diri Norah menarik untuk dikaji lebih mendalam untuk mengetahui keputusan-keputusan yang diambil sebagai upayanya menjadi pribadi yang meng'ada.'

Melalui cerita pertama, bukan hanya Norah yang mengalami beragam persoalan individu yang menunjukkan eksistensinya, tetapi juga dialami oleh ibu, kakak perempuan juga yang mengalami kecemasan, ketakutan, kegentaran, emosi, keputusasaan hingga mengalami ketergantungan terhadap alcohol, yang bermuara pada tercerabutnya ikatan batin di antara keluarga, terutama antara ayah dan anak; antara suami dan istri; ibu dan 
anak laki-lakinya. Dalam pandangan Kierkegaard (2000), setiap saat manusia dihadapkan pada pilihanpilihan untuk menjadikan dirinya 'ada.' Mempertimbangkan pilihan-pilihan itu adalah bagian dari seni yang melibatkan pergumulan tentang kesulitan hidup, penderitaan, tantangan, hambatan, bahaya, yang secara tidak langsung akan menuntun manusia dalam menemukan identitasnya. Seperti yang telah disampaikan di atas, bahwa peristiwaperistiwa penting dalam hidup Norah, seperti masalah ayahnya yang tidak pernah mau berusaha untuk menjalin hubungan dengan anak-anaknya, yang angkuh, diam dan tidak peduli, serta keras, kegagalan perkawinan pertamanya, keputusannya untuk tetap kuliah meskipun harus bekerja keras, dan pilihan karir sebagai pengacara hingga keputusannya untuk menikah kembali dengan laki-laki beranak satu, dan kegundahan dan usahanya memahami kekomplekan hidup dan hubungan adik dan ayahnya yang ternyata terlibat cinta segitiga dengan ibu tiri yang seumuran dengan adiknya hingga peristiwa pembunuhan yang dilakukan oleh ayahnya namun diakui oleh adiknya, Sony, merupakan hasil daripergolakanbatinyangterusmenerus dihayatinya dan dijalaninya. Bukan hanya memikirkannya, Norah memilih untuk tidak menyerah dengan keadaan dan tekanan yang menghimpitnya, Norah adalah gambaran perempuan yang berhasil menatap masa depan dengan positif (TFP, 2009).

Tahap ke-diri-an atau eksistensi diri secara estetis yang membawanya pada puncak frustasi yang dihadapkan pada berbagai macam pilihan yang seringkali membingungkan mampu dilalui Norah dengan mempertimbangkan dan mengikatkan diri pada standard moral tertentu yang menjadi arah dan tujuan hidup. Dalam diri Norah, tahap etis dilaluinya dengan baik. Norah yang berhasil menjadi pengacara memahami bahwa hidupnya adalah pilihannya yang didasarkan pada pertimbanganpertimbangan terhadap apa yang 'baik' dan apa yang 'benar.' Pada tahap etis ini, Norah telah mencapai tingkat integrasi karena mampu memenuhi kewajiban dan peran sosialnya, serta dia mampu bertanggung jawab yang memberinya kesempatan kepada dunia tentangnya sebagai pengacara. Norah yang terikat pada bayang-bayang masa lalunya tentang peristiwa yang memisahkan dirinya dan adiknya, Sony, serta hubungan batin dengan ayahnya yang dingin dan menyiksa dihadapinya dengan tegar. Selanjutnya, ke-dirian Norah, dari segi religious, Norah meskipun secara implisit, digambarkan sebagai seorang yang percaya terhadap zat yang menguasai hidup, Tuhan. Hal tersebut ditunjukkan dengan pilihan nada dering untuk panggilan dari anaknya, Lucie tentang pengagungan Tuhannya (TFP, 2009: 29) selain itu, Norah juga menyebut nama Tuhannya ketika membaca berita-berita peristiwa pembunuhan ibu tirinya yang seumuran adiknya, yang terjadi di rumah orang tuanya yang melibatkan Sonny adiknya dan Ayahnya (TFP, 2009: 72 \& 86). Sebagai manusia, Norah, memahami bahwa dia sekedar menjalankan peran kehidupan yang diberikan oleh Tuhan untuknya. Dia menerima memilih untuk menerima tanggung jawab sebagai pengacara bagi adiknya, meskipun dia mengerti bahwa pilihan itu akan membawanya berhadapan 
dengan ayahnya, sebagai pembunuh sesungguhnya.

Cinta Norah yang kompleks terhadap keluarganya, pengakuan Ayahnya terhadap pembunuhan yang dilakukannya, dan juga pengakuan adiknya terhadap pembunuhan yang sebetulnya dilakukan ayahnya, peliknya hubungan mereka, tidak bisa dihindari, meskipun pada awalnya penuh keraguan, tetapi kemudian Norah merasa harus ikut bertanggung jawab meluruskan hal-hal yang harus dibuat lurus. Tanggung jawab profesinya menuntut dirinya untuk bekerja sebagai pengacara pembela untuk menyelamatkan adiknya atas permintaan ayahnya sendiri (TFP, 2009: 93-95). Sebagai pengacara, dia dituntut untuk bertanggung jawab dan professional karena terikat oleh sumpah jabatan dan juga tanggung jawab moral dan agamanya. Counterpoint pada cerita bagian kedua ini, meskipun masih terlihat berkabur dan samar, tokoh-tokoh kemudian bertransformasi dan bermetamorfosis menjadi burung yang hinggap di ranting pohon, menggambarkan sosok ayah yang seolah-olah siap dengan berbagai kemungkinan yang akan terjadi dengan keputusannya meminta Norah, anaknya untuk membantu anak laki-laki kesayangannya, Sony, menjalani dari jeratan hokum yang disebabkan oleh tindakannya sendiri (TFP, 2009:98). Seperti disebutkan oleh Gaensbauer (2014) dalam penelitiannya bahwa roman ini memiliki ciri-ciri sebagai roman polifonik yang memiliki pluralitas suara dan dialogis. Bakhtin menyebutkan bahwa roman polifonik adalah roman yang ditandai oleh adanya pluralitas suara atau kesadaran dimana suara-suara atau kesadaran itu secara keseluruhan bersifat dialogis. Polifonik yang secara harfiah merupakan 'banyak suara' dapat dikatakan sebagai 'teori baru tentang sudut pandang kepenulisan,' dimana posisi penulis secara bebas berinteraksi dengan karakter-karakter di dalam roman (Mansyur, 2017:243).

\section{Pengalaman Subjektif dan Eksistensi Fanta}

Demikian juga dengan tokoh perempuan dalam cerita kedua, Fanta. Pada cerita kedua ini, tokoh Fanta, seorang Senegal, terpenjara oleh cinta suaminya, Rudy Descas, yang tidak bisa melepaskan diri dari kehidupan dan keluarga besarnya, terutama Ibunya. Fanta terpaksa meninggalkan pekerjaannya sebagai guru sastra di Senegal untuk pindah ke Prancis dan memulai hidup baru. Semenjak tinggal di Prancis, Fanta yang menyadari bahwa hidupnya tidak lebih baik ketika di Senegal, hidup dalam bayangbayang suaminya. Dalam cerita ini dia seolah-olah tenggelam di antara urusan suaminya dan trauma masa lalu kelurganya. Tokoh laki-laki suami Fanta adalah tokoh laki-laki yang sedang berusaha menyelesaikan trauma masa lalunya yang tidak jelas tentang pembunuhan yang melibatkan ayahnya dan hubungan yang komplek atara Ibu dan Manille. Dia mencoba untuk mempertahankan diri dan tetap waras di tengah-tengah tekanan keluarga suami, terutama mertuanya yang memendam kebencian terhadap orang kulit berwarna (TFP, 2009: 256) dengan menyibukkan diri mengurus anaknya tanpa memperdulikan apa yang terjadi dengan keluarga besar Rudy. Tindakan 
represi-represi dengan mengacuhkan dan tidak mengikatkan dirinya dengan rumah keluarga Rudy serta usaha untuk mengubur berbagai macam impian, harapan dan janji yang diberikan Rudy serta mencoba memahami perlakuan tidak mengenakkan dari lingkungan terdekatnya merupakan usaha pertahanan diri Fanta agar tetap eksis.

Tokoh Fanta merupakan saudara sepupu mendiang suami Khady Demba, yang menikah dengan mantan koleganya, guru Ilmu Sastra di Senegal dan memutuskan untuk pindah ke Prancis mengikuti suaminya, Rudy yang terlibat perundungan dengan ketiga muridnya dengan alasan memanggilnya sebagai, 'anak pembunuh' dan 'negro' (TFP, 2009: 188). Secara fisik Fanta digambarkan sebagai perempuan dengan mata lebar kecoklatan, memiliki tulang pipi yang lebar dan pipih dengan bulu mata hitap tebal dan hidung menonjol (TFP, 2009: 109), tubuhnya ramping, tinggi, berotot dan kokoh, berkulit mengkilat (TFP, 2009: 125). Meskipun di Senegal Fanta dapat menjadi guru sekolah menengah, namun di Prancis, Fanta kesulitan untuk menjadi guru karena kesenjangan perbedaan standard kualifikasi antara Prancis dan Senegal.

Fanta muda adalah pribadi yang tenang, cerdas dan pemberani. Keputusan eksistensialnya nya untuk menikah dengan laki-laki yang dicintai dan mencintainya dan pindah ke Prancis mengikuti suaminya merupakan pilihan estetis sekaligus etis. Dikatakan sebagai pilihan estetis karena keputusannya didasarkan pada keinginan dan hasrat yang emosional tanpa pertimbangan yang logis dan matang, hanya didasarkan pada janji- janji suaminya, Rudy Descas yang ingin membahagiakannya di Prancis. Dalam tahap ini, tokoh Fanta digambarkan sebagai perempuan yang pingsan dan tak sadarkan diri, dibutakan oleh cinta, "Et je m'endeuille profondément, car je suis en grand effondrement... Car je suis en grand effondrement" (TFP, 2009: 101). "Dikarenakan aku betul-betul dalam keadaan terpuruk, pingsan tak berdaya."

Kehidupannya selama di Paris bersama suaminya, Rudy Descas yang memberinya janji-janji yang tak kunjung dipenuhi, dengan meninggalkan kehidupan dan pekerjaannya sebagai guru sastra di Senegal, tidak jauh lebih baik dibandingkan kehidupannya di Senegal. Berbekal cinta dan harapan, Fanta memilih untuk belajar bertanggung jawab terhadap pilihannya, meskipun terlihat berat dan melankolik. Perlakuan kasar dan juga rasialis yang diterima Fanta dari keluarga besar suaminya, demikian menyakitkan. Kesadaran diri terhadap apa yang telah dipilihnya sendiri, membuatnya memilih untuk bertahan dan fokus mengurus anaknya, Djibril, meskipun pertengkaran demi pertengkaran terjadi lagi dan lagi.

"Qu'il se fût mal comporté à tel moment et dans telle situation où il importe d'être à la hauteur du drame ou de la joie, il voulait bien l'admettre, mais quel était ce drame, où était cette joie dans la vie réduite qu'il menait avec sa famille, et quelles circonstances particulières n'avait-il pas su affronter en homme accompli ?"(TFP, 2009: 101-102).

"Bahwa dia telah berperilaku buruk pada saat ini dan itu dan dalam situasi di mana penting untuk menjalani hilangnya kegembiraan 
secara dramatis, dia bersedia mengakuinya, tetapi drama apa ini, di manakah kebahagiaan dalam hidup? Bisakah dia (Rudy) memimpin keluarganya, dan dia tidak tahu bagaimana dia mencapai keberhasilan, layaknya seorang lakilaki yang sukes?"

Hidup dalam diam, Fanta seolaholah pingsan (TFP, 2009: 101), Fanta menjadi tidak peduli, dingin, dalam menjalani kehidupannya di Prancis karena tertekan, tergantung secara finansial kepada Rudy yang ternyata memiliki penghasilan yang paspasan, serta terikat pada trauma masa lalunya. Fragmen-fragmen ingatan dan peristiwa pembunuhan yang secara hukum terbukti dilakukan oleh ayahnya terhadap rekan kerjanya, hingga menyebabkan ayahnya masuk penjara dan bunuh diri dengan pistol yang diberikan ibunya, kebencian Rudy terhadap ayahnya, dan kesadaran Rudy tentang peristiwa-peristiwa yang terjadi menggembleng Fanta untuk menjadi seorang yang kuat. Defense mecanisme atau mekanisme pertahanan dirinya adalah selalu merepresi atau melupakan segala apa yang dialami, sebagai tanggung jawab moralnya terhadap pilihannya dan jalan hidup yang dipilihnya. Tahap eksistensinya sudah sampai pada tahap religiusitas, yaitu mengakui bahwa apa yang terjadi pada kehidupannya adalah semua di tangan Tuhan. Dalam cerita kedua ini, terlihat jelas bahwa tokoh Fanta dihadirkan melalui bayang-bayang cerita Rudy yang begitu mendominasi, namunjustru kekuatan Fanta jelas tergambar melalui kemunculan refleksif menggambarkan penerimaan akan hidupnya sebagai apa yang telah digariskan oleh Tuhan. "Tout ce que m'était à venir m'est advenu." (TFP, 2009:103), - "Semua yang terjadi padaku sudah digariskan." (TFP, 2009: 103). "Carjamais, tant que Dieu m'assaillit, je n'en vis un seul à mes cotes." (TFP, 2009:109). - "Karena tidak pernah Tuhan meninggalkanku sendiri disini, Dia selalu ada di sisiku" ( TFP, 2009 : 109). Disini berkali-kali pencerita secara lentur berpindah dari karakter satu ke karakter lain, sebagaimana dikaji oleh Gaensbauer (2014).

Penderitaan Fanta dalam menjalani kehidupan rumah tangga dengan Rudy selama di Paris, Prancis selalu dipahami sebagai insan yang berhubungan dengan apa yang di luar kuasanya, Tuhannya yang maha Agung. Kesalahankesalahan Rudy dalam bersikap dan menuruti perintah Ibunya, meskipun kejam, oleh Fanta dikembalikan kepada Tuhannya meskipun dia juga bertanya dan selalu berkata kepada dirinya sendiri, "Oh, que pouvait-il faire puisqu'il l'aimait? Que puis-je faire d'autre, mon Dieu, brave petit père, bon et brave petit dieu de maman? (TFP, 2009: 135). - "Oh, apa yang telah diperbuatnya? - Tuhan saya mencintainya, apa yang harus saya lakukan? Ya Tuhanku, Bapa yang baik dan Ibu yang penuh kasih." (TFP, 2009: 135). Permohonan dan doa serta harapan kepada Tuhannya tidak pernah putus dilafalkan, karena Fanta percaya bahwa hanya dengan kuasa Tuhan, semua permasalahannya dapat diatasi, "Aidez-nous, bon Dieu" (TFP, 2009:14) - "Ya Tuhan yang Maha Baik, bantulah kami."

Tokoh Fanta dalam karya TFP (2009) memberikan gambaran kekuatan dirinya dalam kesenyapan dan kebatinannya yang selalu menjadi 
perempuan yang dengan penuh keraguan dan keputusasaan melakukan berbagai macam pilihan hidup dan mempertanggung jawabkannya kepada dirinya sendiri, dunia yang diciptakan sendiri dan juga kepada Tuhannya. Kediri-an Fanta yang sengaja 'tampak' ditenggelamkan oleh kehidupan Rudy Descas, suaminya yang memiliki masa lalu yang kompleks dan juga traumatis serta menyedihkan karena perlakuan kasih sayang Ibunya yang menyesatkan, diterima oleh Fanta sebagai takdir yang harus dilewati dan diterima dengan positif. Fanta adalah sosok yang dengan cintanya kepada Tuhan, kepada suaminya dan kepada anaknya, dapat berdamai dengan kondisi hidup yang penuh rintangan dengan diam sebagai bentuk perlawanan. Fanta adalah sosok perempuan yang tegar dalam menantikan kuasa Tuhan untuk berbicara dan bertindak dalam menyelesaikan permasalahanpermasalahan hidupnya, melalui orangorang yang dicintainya. Kesadaran Rudy terhadap perlakuan Ibunya yang ternyata munafik, mengerikan, penuh kebencian dan menyakitkan termasuk membenci cucunya sendiri (anak Rudy dan Fanta, yang berkulit gelap), dan bahkan membenci Rudy dan Fanta merupakan jawaban Tuhan atas masalah mereka. Dalam counterpoint di akhir cerita kedua, Fanta mulai membuka diri dengan bertegur sapa dengan tetangga dekatnya, seolah-olah bertransformasi menjadi burung yang menyenangkan (TFP, 2009:258).

\section{Pengalaman Subjektif dan Eksistensi Khady Demba}

Tokoh Khady Demba pada cerita ketiga merupakan perempuan yang digambarkan sebagai perempuan muda yang naif dibesarkan oleh neneknya dan menikah di usia belia dengan suaminya seorang Afrika. Selama menikah, pasangan ini tinggal bersama keluarga besarnya di rumah yang sangat sederhana dan miskin. Usia pernikahan mereka tidak berlangsung lama. Harapan dan tekanan keluarga besar terutama ibu mertua Khady Demba dan saudara-saudara suaminya agar mereka memiliki keturunan belum juga terpenuhi hingga suaminya meninggal dunia karena sakit. Khady Demba yang tidak lagi memiliki siapa-siapa terpaksa hidup bersama keluarga bekas suaminya yang tidak menyukainya, karena dianggap sebagai beban dan tidak berhaga lagi. Khady Demba, perempuan muda, seorang Afrika tidak tahu apa yang harus diperbuat sehingga ketika diusir dari rumah untuk dikirim secara paksa untuk ke Prancis oleh tokoh Ibu Mertua, dia hanya menurut dan mengikuti tanpa sadar apa yang akan dihadapinya. Berbekal baju seadanya Khady Demba diserahkan kepada agen untuk dikirim ke Prancis dengan alasan mencari pekerjaan dan hidup yang layak (TFP, 2009: 272).

Khady Demba adalah gambaran perempuan muda dari Senegal yang kurang beruntung. Dia anak yatim piatu tanpa mengetahui peristiwa hilangnya bapak/ibunya dari kehidupannya, hidup bersama neneknya dengan Pendidikan sekedarnya. Trauma kehilangan orang-orang terdekatnya, menjadikannya perempuan yang kuat dan tegar dalam kenaifannya. Dinamika wilayah eksistensi Khady Demba pada awalnya secara estetis digambarkan sebagai manusia yang berusaha menghayati kehidupan tanpa 
merujuk pada yang baik dan yang jahat. Hidupnya mengalir begitu saja tanpa kesadaran, sesaat, spontan, tanpa arah dan tujuan (TFP, 2009:259).

Khady Demba hidup dalam kemiskinan, menikah di usia belia dengan laki-laki yang mencintainya, namun meninggal tanpa meninggalkan seorang anak pun, tinggal bersama keluarga mantan suaminya, dianggap sebagai beban dan diusir dari rumah mertua untuk pergi ke Prancis mencari Fanta, sepupunya yang menikah dengan orang Prancis. "Car jamais, au plus fort de l'affliction et de l'épanouissement, elle ne regretterait la period de sa vie ou son esprit divaguait dans l'espace restreint, brumeux, protecteuretannihilant dessonges immobiles, au temps ou elle vivait dans sa belle-famille." "Karena tidak pernah, pada puncak penderitaan dan ketaksadarannya, dia seakan tidak menyesali periode hidupnyaketikapikirannyaterkungkung pada ruang terbatas, suram, kaku dan membisu, kosong jiwa dan kehilangan segala mimpi, pada saat dia tinggal di mertuanya» (TFP, 2009: 312). Kierkegaard(2000)menyebutkanbahwa tahap dimana manusia mencapai pada puncak ketidakberdayaan, disanalah keputusan harus dibuat, apapun itu, bahkan tidak memilihpun adalah suatu keputusan.

Kesadaran Khady Demba mulai muncul ketika menyadari bahwa dirinya menjadi pribadi yang bebas setelah mengikuti semua perintah mertuanya untuk mengikuti laki-laki yang akan membawanya menuju Prancis. Setelah perjalanan panjang, melelahkan, membingungkan, Khady Demba yang membisu mencoba menjalani hidupnya dengan apa adanya. Meskipun Khady Demba mempertanyakan esensi perbedaan antara dirinya dengan 'mereka', Khady Demba dapat menjalani hidupnya dengan khidmat tanpa banyak mengeluh, "Entre eux et moi, quelle différence essentielle? après quoi elle riait intérieurement, ravie de s'être fait à elle-même une bonne plaisanterie, et se disait: C'est que je suis, moi, Khady Demba!" - "Antara mereka dan aku, berbedakah esensinya? setelah dia menertawakan dirinya sendiri, di batinnya, ia mengaggap hal itu sebagai lelucon yang bagus, dia berkata pada dirinya sendiri: Itu karena aku, ya aku, Khady Demba!" (TFP, 2009: 326).

Cemoohan-cemoohan dari saudarasaudara ipar dan juga mertuanya, seolah berlalu begitu saja. Hidup terus bergulir. Melalui tokoh Khady Demba, pembaca diajak untuk merefleksikan kebijaksanaan hidup yang dipilihnya. Diam dan menjalani kehidupan dengan apa adanya, sebagai fragmen kehidupan ke-diri-annya. Meskipun diperlakukan secara tidak manusiawi dan dihina nilai-nilai kemanusiaannya, melalui Khady Demba, Ndiaye seolaholah menyampaikan pandangan eksistensialnya, "But the person who mocks others mocks himself, and it is not meaningless but is rather profound mockery of yourself, a tragic proof of how flabby your soul is, that your view of life is concentrated in one single sentences: "I say simply Either/ Or." (Kierkegaard, 2000:72).

Manusia etis seperti yang digambarkan melalui Khady Demba berpaling ke dalam dirinya sendiri dan mengubah hidup yang tadinya hampa menjadi berarti melalui pilihan autentiknya sehingga dapat mencapai kebebasan, yaitu pemahaman dan penguasaan terhadap diri. Khady Demba tidak malu dan tidak marah 
ketika dunia sekelilingnya mengkhianatinya. Dia selalu mencoba memahami apa yang terjadi terhadap dirinya. Termasuk pilihannya untuk bertahan menjadi menjaja sex murahan tapi bermanfaat bagi orang lain, mucikari yang merawatnya dan juga bagi remaja yang menolongnya, Lamine, ketika dia terdampar di pantai setelah melompat dari perahu yang akan membawanya ke Prancis, Eropa. Penelitian Benoit (2019) menyimpulkan bahwa Khady Demba merupakan gambaran narasi tentang imigrasi ilegal yang menunjukkan hubungan yang tidak seimbang antara Afrika, negara bekas jajahan, dan Eropa sebagai negara yang pernah menjajah, yang didasari pada motivasi-motivasi sosial, ekonomi, dan politik.

Kesakitan dan luka yang dideritanya tidak menyebabkan dia berhenti bekerja, karena dia adalah Khady Demba. Manusia yang memilih kebebasannya, termasuk keputusannya untuk menerima ajakan Lamine untuk menjadi imigran gelap yang penuh resiko, berbahaya, dengan nyawa sebagai taruhannya. Khady Demba yang tidak memiliki apa-apa dan siapasiapa lagi, siap untuk bertransformasi, melepaskan segala kepedihan dan kesedihannya selama di dunia, tugas hidupnya telah diselesaikannya dengan sebaik mungkin tanpa penyesalan.

"Etelle, Khady Demba, quin'avaithonte de rien, ...C'est moi, Khady Demba, songeait-elle encore à l'instant ou son crane heurta le sol et ou, les yeux grands ouverts, elle voyait planer lentement pardessus le grillage un oiseau aux longue ailes grises - c'est moi, Khady Demba, songea-t-elle dans l'éblouissement de cette révélation, sachant qu'elle était cet oiseau et que l'oiseau le savait'" (TFP, 2009: 326-327).
"Dan dia, Khady Demba, yang tidak malu akan apapun... Ini aku, Khady Demba, dia masih berpikir saat tengkoraknya menghantam tanah dan atau, dengan mata terbuka lebar, dia melihat dirinya melayang perlahan, bagaikan burung terbang dan burungpun mengetahuinya." (TFP, 2009: 326-327).

Khady Demba dalam roman TFP (2009) merupakan gambaran manusia yang belum lengkap eksistensinya menurut kaca mata Kierkegaard, karena fase religiusitas terhadap ke-diri-an tokoh ini sama sekali tidak ditemukan. Padahal, menurut Kierkegaard (2000), eksistensi manusia akan ditentukan pada relasi terhadap Tuhannya. Kebutuhan terhadap hubungan dengan Ilahiah menjadi penting karena apa yang terjadi terhadap hidup, semua berdasarkan kuasa Ilahi. Hal ini berbeda dengan tokoh pertama, Norah dan tokoh kedua, Fanta. Norah meskipun tersirat merupakan pribadi yang memiliki hubungan dekat dengan Tuhannya. Hal tersebut terungkap melalui nada panggil telpon anaknya yang menunjukkan spiritualitasnya terhadap Tuhannya (TFP, 2009: 29). Norah bangkit dari keterpurukan dan keputus-asaanya dan memilih menjadi manusia yang bertanggung jawab terhadap hidupnya. Dia dengan sadar melanjutkan pendidikannya hingga menjadi pengacara.

Selain memiliki kesamaan ras, ketiga tokoh perempuan, yaitu Norah, Fanta, dan Khady Demba, memiliki pengalamanyangmenyakitkanditinggal dan ditolak oleh orang terdekat mereka. Norah kecil (8 tahun) ditinggal oleh Ayahnya kembali ke Dakkar dengan 
alasan akan membesarkan anak lakilakinya dengan cara bermartabat selayaknya laki-laki Senegal. Ayahnya dalam surat yang ditinggalkan untuk anak perempuan kecilnya mengatakan bahwa untuk alasan membuka usaha di Dakkar, kedua gadis kecil, Norah dan kakak perempuannya ditinggal bersama ibu mereka di Prancis, dalam kondisi yang merana terpisah dengan salah satu anaknya tanpa sepatah katapun dari ayahnya dan miskin hingga terlilit hutangdan harusbekerja sebagaipelacur (TFP, 2009: 51). Perasaan trauma ditinggalkan dan tidak berguna karena terlahir sebagai perempuan dirasakan Norah hingga dewasa. Berbeda dengan adik laki-lakinya yang dibawa ke Dakkar hidup dengan kemewahan karena keberhasilan ayahnya membuka Desa Wisata yang sukses. Norah dan kakak perempuannya yang beberapa kali dikirim ke rumah ayahnya untuk berlibur, mencoba berdamai dengan trauma masa kecilnya untuk memenuhi panggilan ayahnya untuk membantu ayahnya yang telah menjadi bangkrut dan menjadi pengacara untuk Sony, adik laki-laki yang digadang-gadang ayahnya akan menjadi laki-laki sukses, ternyata terlibat kasus pembunuhan yang menyebabkan ia dipenjara (TFP, 2009: 4). Demikian juga dengan Fanta yang ditolak oleh mertuanya karena masalah ras.

\section{SIMPULAN}

Roman Trois Femmes Puissantes (2009) karya Marie Ndiaye memberikan gambaran tentang perjuangan ketiga perempuan yaitu Norah, Fanta, dan Khady Demba untuk terus mengada. Perjuangan-perjuangan mereka untuk terus eksis di tengah- tengah tekanan-tekanan sosial, budaya, dan ekonomi dimaknai sebagai suatu komitmen mereka dalam mencapai tujuan hidup secara lebih bermartabat. Kesadaran terhadap diri dalam mencapai kebebasan untuk memilih tindakan-tindakan merupakan upaya pemberdayaan diri terhadap perempuan yang direpresentasikan oleh penulis melalui ketiga tokoh ini.

Keputusan-keputusan yang diambil oleh para tokohnya didasarkan pada pertimbangan-pertimbangan moralitas tindakan untuk menjadikan diri mereka ada dan pentransformasikan potensi-potensi diri menjadi aktualitas. Norah memilih untuk berdamai dengan keluarga dan dirinya berusaha untuk tetap meneruskan hidupnya bersama keluarga barunya. Fanta dapat menemukan kedamaian terhadap dirinya melalui Tuhan dan jawaban-Nya terhadap doa-doanya. Sedangkan Khady Demba meskipun kehidupannya berakhir tragis, seperti halnya Sisipus dalam tokohnya Camus, dapat dibayangkan bahwa dia bahagia dengan pilihannya.

Masih banyak hal yang dapat digali lebih dalam melalui roman ini, misalnya tentang human trafficking dan perbudakan kaum imigran di Afrika di Eropa, kaitan karya ini dengan karya yang lain, teknik bercerita penulis, hubungan karya dengan penulisnya dan juga tentang bagaimana tanggapan pembaca di Indonesia terhadap roman TFP (2009).

\section{UCAPAN TERIMA KASIH}

Penelitian Mandiri tahun 2020 ini terselesaikan berkat kerja sama semua pihak. Secara khusus peneliti mengucapkan terima kasih kepada 
semua pihak yang telah membantu terselesainya penelitian ini, terutama kepada para pemimpin LPPM UNY, Fakultas Bahasa dan Seni UNY, dan juga Jurusan Pendidikan Bahasa Prancis, serta para dosen, yang terlibat dalam diskusi dan memberi masukan terhadap hasil dari penelitian ini.

\section{DAFTAR PUSTAKA}

Artanti, Y. (2020). Konsep Diri Perempuan di Persimpangan Budaya dalam Autobiografi Stupeur et Tremblements Karya Amelie Nothomb. Litera Jurnal Penelitian Bahasa, Sastra dan Pengajarannya, 19(1), 72-93. doi:10.21831/1tr. v19i1.30465

Benoit, M. (2019). Dire la migration, «Khady Demba» dans Trois femmes puissantes de Marie Ndiaye. Journal of the African Literature Association, 13(2), 218-230, DOI: 10.1080/21674736.2019.1614268.

Gaensbauer, D. B. (2014). Migration and Metamorphosis in Marie Ndiaye's Trois Femmes Puissantes. Studies in 20th \& 21st Century Literature, 38(1). http://dx.doi.org/10.4148/23344415.1004.

Garot, E. (2017). Pergumulan Individu dan Kebatiniahan. Yogyakarta : PT Kanisius.

Hadiwijono, H. (2016). Sari Sejarah Filsafat Barat 2, cetakan ke-28. Yogyakarta: PT. Kanisius.

Harjito. (2014). Kemandirian Perempuan Jawa dalam Cerita Tradisional. Litera Jurnal Penelitian Bahasa, Sastra, dan Pengajarannya, 13(2), 316-325. https://doi. org/10.21831/1tr.v13i2.2584.
Hassan, F. (2014). Psikologi-Kita \& Eksistensialisme. Depok: Komunitas Bambu.

Hong, H. V., \& Hong, E. H. (2000). The Essential Kierkegaard. USA: Princeton University Press.

Kierkegaard, S. A. (2009). Concluding Unscientific Postscripts to the Philosophical Crumbs. (Alastair Hannay, edited \& transl). USA: Cambridge University Press.

Imorou, A. (2013). Humaines et épanouies. Trois Femmes Puissantes et Les Figures littéraires des Africaines. Association for French Studies in Southern Africa (AFSSA), (43), 40-62. https://journals.co.za/content/ french/2013/43EJC145917.

Manshur, F.M.(2017). TeoriDialogisme Bakhtin dan Konsep-Konsep Metodologisnya Bakhtin's Theory of Dialogism and Methodological Concepts. SASDAYA, Gadjah Mada Journal of Humanities, 1(2), 235249. https://doi.org/10.22146/ sasdayajournal.27785.

NDiaye, M. (2009). Trois Femmes Puissantes. Paris: Gallimard.

Nina, W. (2013). La vie de trois femmes représentée par deux auteurs différents : les "bonnes femmes" de Montaigne vs. les "femmes puissantes" de Marie Ndiaye. [Thesis tidak diterbitkan]. Universitas Ghent.

Nurhayati, A. (2019). Intersectioning Oppression of Gender and race in Toni Morrison's “The Bluest Eye abd God Help The Child". Litera, Jurnal Penelitian Bahasa, Sastra, dan Pengajarannya, 18(3), 379-394. https:// doi.org/10.21831/1tr. v18i3.27796. 
Parent, A. M. (2013). À leur corps défendant: défaillances et excrétions dans Trois femmes puissantes de MarieNdiaye.L'EspritCréateur, 53(2), 76-89, https://doi.org/10.1353/ esp.2013.0026.

Ritzer, G., Stepnisky, J. (2019). Classical Sociological Theory. (Ahmad Lintang Lazuardi, transl.). Yogyakarta: Pustaka Pelajar.

Syafe'i, I. (2015). Subordinasi Perempuan dan Implikasinya terhadap Rumah Tangga. Jurnal Studi Keislaman. 15(1), 143-166. https://doi.org/10.24042/ajsk. v15i1.716.

Wiyatmi. (2010). Citraan Perlawanan Simbolis Terhadap Hegemoni Patriarki Melalui Pendidikan dan Peran Perempuan di Arena Publik dalam Novel-Novel Indonesia. Atavisme, 13(2), 243-256. https:// doi.org/10.24257/atavisme. v13i2.135.243-256.
Wiyatmi.,Suryaman,M.,\&Swatikasari, E. (2016). Dekonstruksi terhadap Kuasa Patriarki Atas Alam, Lingkungan Hidup, dan Perempuan dalam Novel-Novel Karya Ayu Utami. Litera, Jurnal Penelitian Bahasa, Sastra, dan Pengajarannya, 15(2), 282-291. https://doi. org/10.21831/ltr.v15i2.11829.

Yuliawati, S. (2018). Perempuan atau Wanita? Perbandingan Berbasis Korpus Tentang Leksikon Berbias Gender. Paradigman Jurnal Kajian Budaya, 8(1), 53-70. http://dx.doi. org/10.17510/paradigma.v8i1.227. 